\title{
ECONOMIC DISLOCATION AND CONTRACT RENEGOTIATION IN NEW ZEALAND AND JAPAN: A PRELIMINARY EMPIRICAL STUDY
}

\author{
Luke R Nottage*
}

This article reports on results so far from ongoing empirical research into attitudes and practices in New Zealand and Japan as to contract renegotiation in cases of extreme economic dislocation. It reports primarily on a survey administered to students in both countries. It adds some preliminary results from a more ambitious survey and follow-up interviews with companies; final results will follow in early 1997. In the interim, the article draws some possible implications for reform of the law of frustration of contract, and for legal theory more generally.

\section{CONTRACT LAW IN ACTION}

It has been said: ${ }^{1}$

The commercial character of contracts rests in many cases on the assumption that each of the parties will play his part in the relationship in accord with the reasonable expectations of the others. That is why parties to continuing supply contracts, where price and supply are the subjects of written agreement, expect and usually receive a sympathetic response when the cost of performing their obligations is affected by a sudden rise in prices of raw materials or by a dramatic change in exchange rates. To the lawyer, the written contractual formula ends all

* Lecturer in Law, Victoria University of Wellington; Associate, JHJ Crawford Law Office. This research was supported by a Collaborative Research Grant from the NZ Asia 2000 Foundation. The author also thanks the NZ Legal Research Foundation and the participants at its Colloquium on Long-Term Contracting held in Auckland on 19 November 1996. The author particularly thanks Akira Fujimoto (Research Fellow, Asia Reseach Center, Osaka University of Law and Economics) for assistance in statistical analysis of the results. 
argument; to the businessman, it merely provides the base for a further round of negotiation in the sure faith that he will not be bound by the letter of the agreement.

New Zealand readers may well imagine that this quote encapsulates a peculiarly Japanese attitude towards resolving contract disputes, and towards contract law itself. ${ }^{2}$ In fact, it comes from a paper presented by Dr George Barton at a New Zealand Law Conference in 1980 . His views stemmed partly from his experience in advising some of New Zealand's best known businesspeople. ${ }^{3}$ At the conference, however, Richard Craddock QC was reported as being equally convinced that if New Zealand lawyers believe that the "reasonableness" principle (advanced by Dr Barton) "is what the commercial community wants, then 'we misread our market' ... the businessman expects performance and certainty, and to lose the latter diminishes the likelihood of the former".4

One way to resolve such conflicting views is systematic empirical research. In the United States, Stewart Macaulay's extensive interviews of Wisconsin businesses in the early 1960s revealed a pattern closer to that suggested by Dr Barton. ${ }^{5}$ In the United Kingdom, a study by Hugh Beale and Tony Dugdale of manufacturers in Bristol in the 1970s led to similar conclusions. ${ }^{6}$ This provides a backdrop, still frequently overlooked, to similar observations in somewhat less systematic studies by Japanese commentators in the 1960s, translated into English in the early 1970s. ${ }^{7}$ None of this research was referred to at the New Zealand Law Conference in $1980 .{ }^{8}$ This is unsurprising, since New Zealand lacks

Foreign writers emphasising this sort of attitude among Japanese include eg, $\mathrm{R}$ March The Japanese Negotiator: Stategy and Subtlety beyind Western Logic (Kodansha International, Tokyo, 1988), especially ch 6 . New Zealanders may still have fewer fixed preconceptions than North Americans, Europeans, or even Australians, due in part to fewer and differing historical contacts with Japan see L Nottage "Contract Law and Practice in Japan: An Antipodean Perspective" in H Baum (ed) Japan: Economic Success and Legal System (de Gruyter, Berlin, 1996) 197.

3 Specifically, for instance, Sir Brian Todd, described by Lord Wilberforce in CIR $v$ Europa Oil (NZ) Ltd [1971] NZLR 641, 644 as "an adroit and effective [contract] negotiator".

$4 \quad[1981]$ NZLJ $379,380$.

5 S Macaulay "Non-Contractual Relations In Business: A Preliminary Study" (1963) 28 Am Soc Rev 55.

$6 \quad \mathrm{H}$ Beale and T Dugdale "Contracts between Businessmen: Planning and the Use of Contractual Remedies" [1978] Brit J Law \& Soc 45.

7 See T Kawashima "The Legal Consciousness of Contract in Japan" (1974) 7 Law in Japan 1; Y Noda Introduction to Japanese Law (A Angelo, trans and ed, Tokyo University Press, Tokyo, 1976). 
a tradition of socio-legal inquiry. ${ }^{9}$ To begin filling this void, this article reports on results from a survey organised from Japan, recently administered to both law and business students in that country and to a more limited extent in New Zealand. As Part II explains, this provides a useful starting point for ongoing empirical research into contract expectations and practices of businesses in both countries, some of which is also reported on in this article.

Macaulay's findings have profoundly influenced contract law teaching in the US. ${ }^{10}$ Primarily through "relational contract" theory, developed initially by Ian Macneil, they have also underpinned major developments in contract law theory and legal theory generally. ${ }^{11}$ The effect of this can be seen in case law and proposals for legislative reform. ${ }^{12}$ To a lesser extent, this has been also been so in the UK and in Japan. ${ }^{13}$ By contrast, the effect on contract law teaching in New Zealand has been minimal. ${ }^{14}$ Yet practitioners and judges are already grappling with the empirical background to contemporary contracting

9 Difficulties stemming from this are also highlighted in a preliminary comparison of civil litigation trends in New Zealand and Japan: L Nottage and C Wollschläger "What Do Courts Do?" [1996] NZLJ 369.

10 Particularly through the "Wisconsin school": see eg L Friedman Contract Law in America - A Social and Economic Case Study (University of Wisconsin Press, Madison Wisc, 1965); L Friedman and S Macaulay "Contract Law and Contract Teaching: Past, Present, and Future" [1967] Wisc L Rev 805; S Macaulay, J Kidwell, W Whitford and M Galanter Contracts: Law in Action (The Michie Company, Charlottesville Va, 1995).

11 For example see I Macneil "The Many Futures of Contract" (1974) 60 So Cal L Rev 691; Goetz and R Scott "Principles of Relational Contracts" (1983) 67 Virg L Rev 1089 (law and economics); J Feinman "Relational Contract and Default Rules" (1993) 3 So Cal Interdisc LJ 43 (critical legal studies); M Frug "Rescuing Impossibility Doctrine: A Postmodern Feminist Analysis of Contract Law" (1992) 140 U Pa L Rev 1029 (feminist jurisprudence); R Barnett "Conflicting Visions: A Critique of Ian Macneil's Relational Theory of Contract" (1992) 78 Virg L Rev 1175 (contemporary liberalism).

12 N Crystal "An Empirical View of Relational Contracts under Article Two of the Uniform Commercial Code" [1988] Ann Surv Am L 293; H Sono "UCC Dai Ni Hen (Hanbai) no Kaisei Sagyo ni miru Gendai Keiyaku Ho no Ichi-Doko [The Revision of UCC Article 2: PEB Study Group Reports, Llewellyn's Rich Legacy, and Modern Contract Law] (1)" (1994) 44 Hokudai Hogaku Ronshu 837.

13 See P Atiyah An Introduction to the Law of Contract (5 ed, Clarendon Press, Oxford 1995) 50-53; T Uchida "The New Development of Contract Law and General Clauses - A Japanese Perspective" in The Organizing Committee of the Symposium (ed) Proceedings of the Symposium Japanese and Dutch Laws Compared (International Center for Comparative Law and Politics, Tokyo, 1993) 119.

14 For a rare mention, see J Burrows, J Finn and S Todd Cheshire E Fifoot's Law of Contract (Butterworths, Wellington, 8th NZ ed, 1992), 26-27. 
and with relational contract theory. ${ }^{15}$ Parts III-V of this article therefore consider some of the implications for New Zealand legal education of even the preliminary results from this survey. Part VI then revisits a recently revived discussion paper on reforming the law of frustration, which draws on empirical and comparative insights dovetailing quite neatly with the preliminary results from this survey as well as some from the ongoing study. Part VII concludes by sketching some implications for legal theory generally.

Even more so than Macaulay's pioneering research, this is a preliminary study. Results of ongoing research will be reported more fully in early 1997, and theoretical points developed further. ${ }^{16}$ This interim report aims to reveal some of the richness that comparative empirical research can add to the rather austere landscape of contemporary New Zealand contract law.

\section{THE KATO/YOUNG SURVEY: A BASIS FOR FURTHER RESEARCH}

The Kato/Young survey was devised by the Research Center for International Comparisons of Legal Consciousness, based at Nagoya University Law School, and an interdisciplinary group of nine researchers from other Japanese universities. ${ }^{17}$ Five others based overseas subsequently became affiliated with this project. ${ }^{18}$ The survey has already been administered in ten countries. ${ }^{19}$ Tentative comparisons for some of those countries were presented at an international conference in Tokyo in 1995, although further data

For instance, a version of relational contract theory was extensively argued in Pizza Restaurants (NZ) Ltd v Pepsico Australia Pty Ltd (Unreported, CL 35/92, HC Auckland, Robertson J, $24 / 3 / 94)$.

In a special issue of the NZ Law Review (forthcoming, April 1997).

17 Directors of the Center are Professor Masanobu Kato (Nagoya University) and Professor Michael Young (Columbia University). The former has also been instrumental in organising a symposium comparing aspects of legal consciousness in East Asian societies, primarily between Japan and Korea (subsequently reported in (1992) 1007 Juristo 12). The primary impetus for that focus was a nation-wide survey into legal consciousness carried out in Korea in 1991 (see Song (ed) 1996, reviewed by L Nottage (1996) 26 VUWLR 600, especially at 605-606). Kato has also recently published an inquiry into another aspect of key interest to the Center, private property ("A Perspective on the Structure of the Emergence of Property Right Conceptions" (1995) 1069 78 Juristo). Two of the the nine other researchers based in Japan, contributing to the Center's present research project into contract consciousness, are in fact Chinese, and one is Korean.

18 They are academics from Columbia University, Humboldt University, Hanoi University, and Victoria University of Wellington (this author); and a Thai jurist now in private practice.

19 Japan, China, Korea, Philippines, France, United States, Australia, Hong Kong, Thailand, and New Zealand. 
collection outside Japan and more detailed comparisons are still underway. ${ }^{20}$ The final results for Japan have recently been published in Japan's leading law journal. ${ }^{21}$ Some partial results for New Zealand have also been collected. ${ }^{22}$ Some preliminary observations can therefore be made and some directions outlined for further research, some of which is already underway.

Multiple variants of the survey were administered in each country because respondent "nationalism", or systematic bias towards certain other countries, was considered a distinct possibility. For New Zealand, the organisers formulated six variants:

(i) Japanese buyer - New Zealand seller (of timber)

(ii) New Zealand buyer - Japanese seller (of ships)

(iii) New Zealand buyer - New Zealand seller (of oil products)

(iv) "Country A" buyer - "Country B" seller (of commodity X)

(v) New Zealand buyer - US seller (of oil products)

(vi) US buyer - New Zealand seller (of oil products)

All variants are based on the same scenario. Although seemingly not etched on the collective consciousness in New Zealand to the degree it is in Australia, the scenario is close to the "sugar case" dispute which flared up between a consortium of Japanese buyers and a Queensland seller in the late 1970s. ${ }^{23}$ Briefly, it postulates a long-term supply contract concluded at a fixed price well below the then market price, followed by an even greater fall in the market price which prompts the buyer to call for renegotiation. The scenario is divided into four stages, interspersed with eight propositions ( $q A \sim q H)$ with

20 M Kato and A Fujimoto "An International Comparison of Contract Consciousness - Which is More Unique, Japan or the US?" (1995) Paper presented at the 1995 Annual Meeting of the Research Committee on Sociology of Law (International Sociological Association), "Legal Culture: Encounters and Transformations" (Tokyo, 1-4 August 1995) Section Meetings Supplement 3, 39 .

21 M Kato and M Young "Nihonjin no Keiyakukan [Conceptions of Contract held by Japanese]" (1996) 1096 Juristo 44.

22 So far, the sample is much smaller - a total of 475: 362 from Victoria University, 114 from Massey University, and 9 from Waikato University. (It is hoped that this preliminary report will encourage colleagues at other New Zealand universities to administer the survey to their students as well.) Data entry has also proven laborious, and only a total of 368 (254 from Victoria and 114 from Massey) have been entered so far. Some of those did not answer all questions: hence the varying sample sizes used for the analysis summarised in Tables 1 to 3 below (at III V).

23 March, above n 2, 97-107. 
respect to which respondents are requested to indicate whether they strongly agree (by circling 1 on the questionnaire form), agree (2), are uncertain (3), disagree (4), or strongly disagree (5). ${ }^{24}$

(i) Buyer and seller conclude a five-year contract at a fixed price half that of the then prevailing market price; but a year later the market price drops to a quarter of its original price. The buyer, now locked into an expensive contract, and in poor shape financially, attempts to renegotiate terms. The seller initially agrees to postpone sales for one year. However, during that second year, the price drops further, to one fifth of the original market price. The buyer then repeatedly attempts to renegotiate a lower contract price; but, despite negotiations, the seller refuses.

$q A$. It is imprudent to conclude a contract for five years for the products, whose market price fluctuates markedly.

$q B$. It is natural to alter the contract terms if the market price falls greatly, so it is reasonable for the buyer to take the actions set out in (i).

$q C$. Despite the great fluctuation in market price, the seller's refusal to lower the contract price demonstrates too inflexible an attitude.

(ii) At the start of the fourth year, the buyer decides to refuse to take delivery of the goods.

$q D$. This action by the buyer should be supported.

(iii) The seller insists on shipping the goods, so they begin accumulating in the buyer's port. After three months of this, towards the end of the fourth year, the seller agrees to reduce the contract price by one tenth.

$q E$. These actions by the buyer should be not be supported because one should observe terms once a contract is made.

$q F$. These actions by the buyer are ethically sordid.

qG. It is ridiculous for the seller to finally agree to reduce the contract price, despite the originally fixed price.

(iv) It turns out that the buyer would have risked bankruptcy had it kept to the original contract terms.

$q H$. Since contract terms cannot be kept upon bankruptcy, the buyer would inevitably take all the above actions. 
Before outlining some significant results, three possible difficulties with the design of this survey should be considered. ${ }^{25}$ First, at the international conference in August 1995, questions were raised as to whether the sample of law and commerce students was representative, and whether they could be good proxies for lawyers and businesspeople respectively or for the commercial world generally. The organisers had considered surveying lawyers and businesspeople directly, but ended up surveying students.

However, this is understandable. There would have been even greater practical difficulties in administering the survey in so many countries, particularly given the minimum sample size needed for each questionnare variant. Admittedly, students surveyed in Japan tend to be from "good" universities. However they can be seen as representative at least of the Japanese elite, and certainly of a significant force in Japanese legal and commercial circles. The potential for students surveyed to be unrepresentative is also minimised in countries like New Zealand, where all universities are state-funded. On the other hand, it may be worthwhile to survey students doing commerce courses from a broader range of tertiary institutions, such as polytechnics. Finally, preliminary results to versions (iii) and (i) of the Kato/Young hypothetical included in a survey currently being administered to New Zealand and Japanese firms are revealing a similar pattern to that obtained from combined law and commerce student respondents in each country.

A second, more difficult question is whether the scenario is overly abstract. Macaulay's initial research, and even more so his later work, ${ }^{26}$ demonstrated the value of in-depth exploration of organisations and markets in relatively distinct areas of activity, to generate a better feel for the complex way in which norms in contracting situations can be played out. ${ }^{27}$ Further, specifically with regard to both social and legal responses to extreme

24 The scenario and questions are not reproduced verbatim, because multiple survey variants were used. However, despite some infelicities in expression, the wording in the ensuing text above is as close as possible to that used in the student surveys. A further set of survey questions were included to compare respondents' attitudes towards authority and power, building on earlier work by Adorno. Preliminary data for New Zealand has not yet been fully analysed, but results from Japan suggest the need for closer analysis of the way respondents develop attitudes and expectations as a particular dispute unfolds (A Fujimoto "Keiyaku Sonjundo to Kenryoku Shiko [The Extent to which Contracts are Adhered to, and Orientation towards Authority]" (1996) 1096 Juristo 64). This accords with insights from relational contract theory (Macneil above $n$ 11), some feminist theory (Frug above n 11), and neo-proceduralism (below n 155). It also reinforces the importance of follow-up interviews in the further study currently underway.

25 Cf V Taylor "Nihonjin no Keiyakuishiki - Australia kara no Kansatsu [Contracts Consciousness of the Japanese: Observations from Australia]" (1996) 1096 Juristo 71.

26 Eg S Macaulay "Private Legislation and the Duty to Read - Business Run by IBM Machine, the Law of Contracts, and Credit Cards" (1966) 19 Vand L Rev 1051.

27 S Moore "Law and Social Change: The Semi-Autonomous Field as an Appropriate Subject of Study" [1973] Law and Society Review 719. In this sense, Macaulay anticipated the current 
economic dislocation affecting contractual relations, Macaulay and others have asked: "do the rules change when the game gets bigger?". ${ }^{28}$ The US cases they review strongly suggest that they do. An example is the way in which Westinghouse Electric Corporation staved off potential bankruptcy in the late 1970s and early 1980s, from power company claims aggregating US $\$ 2.6$ billion regarding supply of uranium fuel for nuclear power plants constructed by Westinghouse. ${ }^{29}$ Other case studies, such as the US government's bailout of Lockheed Aircraft Corporation in 1971, also show vividly how legal norms are played out in complicated political and social arenas. ${ }^{30}$

In present survey variants, the hypothetical contract amount is large, and the potential bankruptcy of the buyer is revealed at stage (iv). However, as Veronica Taylor has pointed out, the present survey abstracts factors like details of the business relationship between the two parties, their absolute size and relative position within the industry, and their experience in international transactions. ${ }^{31}$ Another key factor in the Sugar Case, as in many major US cases, was its highly political nature. The Queensland supplier, CSR Ltd, was controlled by the Queensland state government. The dispute became a bilateral trade issue and, when the goods started to back up in Tokyo Bay, the Japanese government became actively involved. The Ministry of Agriculture and Fisheries developed new legislation to rationalise the sugar refining industry in Japan. The Ministry also exercised administrative guidance over the buyers, in the search for a rational solution to the problem. ${ }^{32}$ On the other

"interpretive" turn in legal sociology, for which see Y Wada, Hoshakaigaku no Kaitai to Saisei Postmodern o koete [The Deconstruction and Rebirth of Legal Sociology: Beyond Postmodernism] (Kobundo, Tokyo, 1996).

28 Above n 11, 681-770.

29 S Ota and M Young "Keiyaku Kankyo no Hendo to Keiyaku Sonjun - Jirei Kenkyu o chushin ni [Adherence to the Contract and Changes in the Contracting Environment: Focusing on Case Study Research]" (1996) 1096 Juristo 41, note some parallels between the Westinghouse litigation and the survey hypothetical based on the Sugar Case. However, one important difference in the former was the innovative approach of the trial judge. On two occasions, Judge Merhige found that Westinghouse was not excused, but pressed the parties to settle and eventually limited the remedy so that there was some loss-sharing. The Court of Appeals then did excuse Westinghouse, but used its equitable powers to fashion a result it saw as fair. Not surprisingly, many of the other Westinghouse suits settled. Another important consideration was the highly regulated nature of the industry at the time, and hence the political sensitivity of the suits. Macaulay et al, above n 10, 742-770.

30 Macaulay et al, above n 10, 669-678.

31 Above n 25, 72.

32 See March, above $n$ 23. Such "guidance" is supposed to be of no coercive effect, and to leave the regulated parties the option of voluntarily refusing to comply; but at least in the 1970s, it was still highly persuasive. See M Young "Judicial Review of Administrative Guidance: Governmentally Encouraged Consensual Dispute Resolution in Japan" (1984) 84 Col L Rev 924. 
hand, some abstraction is inevitable in any survey research. Further, student respondents did not tend to mechanically circle "3", indicating "uncertainty", which could be interpreted as a plea for more detail in order to be able to respond to each proposition more definitely. 33

A third question is whether the hypothetical scenario is realistic, in that the hypothetical contract does not contain any clauses providing for economic dislocation and adjustment of the contractual relationship. Taylor suggests that contracts used by Japanese parties have changed considerably, and concludes that the Sugar Case may now be merely of historical interest. ${ }^{34}$

There will always be a tension between contracting parties who still deliberately speculate on market movements by agreeing simply on a fixed price even over a lengthy term, and others who agree on that without sufficient deliberation. In some industries, deliberate speculation on an agreed fixed price may be more common, or the parties may carefully draft clauses to allow for some risk sharing or contract adjustment. ${ }^{35}$ Further, drafting practice within those industries can change in line with structural changes in markets. ${ }^{36}$ Thus, issues of contract renegotiation should certainly be related to both legal possibilities and

Although US commentators have tended to see administrative guidance as uniquely Japanese, it is certainly not unknown in the US. A good example is US government "jawboning" during the Vietnam War in the late 1960s, putting pressure on its suppliers and subcontractors to accord military orders priority over civilian contracts. In Eastern Airlines Inc v McDonnell Douglas Corp 532 F 2nd 957 (5th Cir, 1976), such jawboning was held to excuse McDonnell's delays in supplying aircraft to Eastern. In the English tradition, "guidance" is also not unknown, but is often circumvented by detailed statutory provisions. Even then, however, disputes can arise (see, in the context of judicial review, $R v$ Secretary of State for the Environment, ex parte Lancashire County Council [1994] 4 All ER 165).

33 By contrast, that has been a noticeable tendency in responses so far from a similar hypothetical put to Japanese firms. Follow-up interviews of some of those firms may reveal what is driving that tendency.

34 Above, n 25, 71-2. Further, as one New Zealand company respondent has observed, the hypothetical also seems unrealistic in implying that the seller has shipped goods - especially in version (i) involving timber - to the buyer's port, before having had a Letter of Credit opened in its favour. This aspect of the Sugar Case itself, and possible changes in practice, deserve further investigation.

35 See eg the survey of international oil traders by L Trakman The Law Merchant: The Evolution of Commercial Law (Fred B Róthman, Littleton Colorado, 1983) ch 8. See also the strict approach taken by the Californian Court of Appeals towards an oil supplier's force majeure clause in Nissho Iwai Co Ltd v Occidental Crude Sales Inc 729 F 2d 1530 (1984).

36 See eg the study of iron ore export contracts by $\mathrm{T}$ Daintith "The Design and Performance of Long-Term Contracts" in T Daintith and G Teubner (eds) Contract and Organisation (de Gruyter, Berlin, 1986) 164. 
actual practices in contract drafting: ${ }^{37}$ the latter also deserve empirical research. Again, however, this is an aspect which can be less readily incorporated into a survey of students.

A further survey has therefore been devised and partially implemented, addressing these difficulties while building on the Kato/Young survey. First, it is aimed at over 110 firms in New Zealand and over 60 firms in Japan. Secondly, the survey requests follow-up interviews, some of which have already been undertaken. They allow responses to be explained, and a richer picture of particular institutional structures to emerge. Thirdly, the survey includes a part on contract planning and drafting practices actually undertaken by respondent firms, based on a recent survey of US firms. ${ }^{38}$ As mentioned, the results of this research will be reported in early 1997. ${ }^{39}$ However, the Kato/Young survey, and some interesting results summarised below, have already proved useful in formulating hypotheses and advancing this more ambitious project.

\section{NEW ZEALAND AND JAPAN COMPARED}

A first interesting result to emerge from the Kato/Young survey is that even New Zealand students are not too "tough" on the buyer who tries to renegotiate the deal. This is surprising for two reasons. First, the fact that the deal was originally struck at a price highly favourable to the buyer might dispose respondents to think that the buyer should just have to live with it. ${ }^{40}$ Secondly, one might have expected students to be aware that New Zealand law provides little comfort to the buyer in this sort of situation, as Part VI below shows. A second interesting result is the similarity between responses from students in New Zealand and Japan.

Table 1: New Zealand vs Japan

\begin{tabular}{|l|l|l|l|l|l|l|l|l|}
\hline & qA & qB & qC & qD & qE & qF & qG & qH \\
\hline
\end{tabular}

37 This point also emerges in the structure and findings of Macaulay's pioneering study (above $\mathrm{n}$ $5)$.

38 R Weintraub "A Survey of Contract Practice and Policy" (1992) Wisc L Rev 1.

39 Above $\mathrm{n} 16$.

40 This attitude is exemplified by one company's comment on this hypothetical: "The key here is that the deal was hugely favourable to $A$ [the buyer] when struck. The quid pro quo is surely that there are ups and downs; A here is aiming for the best of both worlds". Some commentators in Japan made the same criticism of the Japanese importers during the Sugar Case dispute (Kobayashi, "Tokute Chikai Osutoraria [Australia: So Near and Yet so Far]", quoted in S Tanaka and M Ueno Keiyakuishiki to Bunsho Hyogen [Contract Consciousness and Written Expression] (Nunoi, Tokyo, 1980) 177-179. Yet such views are not so strongly held by New Zealand and Japanese student respondents. 


\begin{tabular}{|l|l|l|l|l|l|l|l|l|}
\hline $\begin{array}{l}\text { NZ } \\
(297)\end{array}$ & 2.23 & 3.0 & 3.04 & 3.39 & 2.47 & 2.79 & 3.61 & 2.48 \\
\hline $\begin{array}{l}\text { Japan } \\
(2855)\end{array}$ & 2.26 & 2.90 & 2.85 & 3.33 & 2.70 & 3.04 & 3.58 & 2.42 \\
\hline
\end{tabular}

Student respondents in both countries generally agree that it is imprudent to enter into this sort of fixed term contract (qA). There is some ambiguity regarding qA. Some respondents strongly disagreed with this proposition (circling " 5 "). Comments so far from surveys and at follow-up interviews of companies (albeit larger New Zealand companies) suggest that these respondents thought it could still be acceptable to commit to a long-term contract, provided careful risk analysis was first undertaken and/or that variable pricing (such as indexation) was agreed on in the contract. In their other responses, these respondents tended to be quite consistently critical of the buyer in this hypothetical, and correspondingly supportive of the seller trying to enforce the original deal. On the other hand, as just noted, the majority tended to think that contracting for a lengthy fixed term remained "imprudent". Since it becomes immediately apparent - from stage (i) of the scenario - that it is the buyer who has got into difficulties, this response can also be interpreted as criticism directed primarily towards the buyer. Thus, perhaps responses to qA are best interpreted merely as indicative of the willingness to enter into long-term contracts generally, and hence of long-term or short-term attitudes towards business dealings. ${ }^{41}$ Responses to subsequent questions are therefore likely to be more revealing as to attitudes towards contract renegotiation per se.

Indeed, student respondents in both countries become uncertain about whether it might be "natural" to alter the terms if the market price falls greatly $(\mathrm{qB})$, as requested by the buyer. Certainly, there is no strong implicit criticism of the buyer. Respondents are also uncertain about whether the seller may have been too inflexible in refusing to reduce that request $(\mathrm{qC})$. Compared to their Japanese counterparts, NZ respondents do become marginally more critical of the buyer when the latter then threatens not to take delivery (qD). Further, when the goods have begun to accumulate in the harbour, they tend to agree that allowing the buyer to carry out this threat should not be condoned, both on legal principle - sanctity of contract ( $\mathrm{qE}$ ) - and, to a lesser extent, on ethical grounds ( $\mathrm{qF}$ ). These appear to be two key questions, because they most clearly set out general principles

41 Responses so far from companies show that New Zealand companies are significantly more likely to agree that entering into five-year contracts is "imprudent", cumpared to Japanese companies. Responses to a further question added to the company survey also show that they are considerably less likely to actually enter into contracts of more than one year, at least domestically. 
for consideration. Thus, perhaps the most striking result is that even $\mathrm{NZ}$ responses to $\mathrm{qE}$ and $\mathrm{qF}$ are not more critical of the buyer.

On the other hand, New Zealand respondents seem even readier to accept that the seller would have had to give in to the request for price reduction at this stage (qG). Respondents also tend to accept that a risk of bankruptcy to the buyer justifies the latter's actions $(\mathrm{qH})$. This may indicate some tenderness towards the buyer, although certain comments from company respondents indicate that this attitude may be born more of necessity. ${ }^{42}$

Overall, law and commerce students in both New Zealand and Japan do not appear to feel too strongly one way or the other. They are perhaps slightly more critical of the buyer. However, as described more fully in Part VI below, this attitude differs quite markedly from that of the courts in both countries, particularly in New Zealand.

Also striking are the similarities between New Zealand and Japanese responses. Responses to $\mathrm{qA}, \mathrm{qB}, \mathrm{qD}, \mathrm{qG}$ and $\mathrm{qH}$ are virtually identical. Japanese respondents are marginally more likely to see the seller as too inflexible when initially refusing the buyer's request for a lower price $(\mathrm{qC})$, and are subsequently more lenient towards the buyer both as a matter of legal principle and on ethical grounds ( $\mathrm{qE}, \mathrm{qF}$ ); but those differences are not statistically significant at the $95 \%$ confidence level. Further, the different trends for law as opposed to business students, and for female as opposed to male students, are broadly similar in both countries. Those trends will be reviewed in Parts IV and V below.

First, however, an aspect emerging only from the survey as administered in New Zealand should be addressed, namely surveys of international students attending New Zealand law and business schools. The question of country bias, where some differences between Japan and New Zealand have become apparent, will also be considered. In both respects, however, further research is needed before any definite conclusions can be drawn.

\section{A Internationalising Legal Education}

One interesting characteristic of the survey of students in New Zealand was the high number of respondents with other than New Zealand nationality. Consistently with the methodology in other countries where the survey was implemented, results from the latter subset were excluded from the sample in deriving the results reproduced in other sections of this article. However, a comparison with results from respondents of New Zealand nationality reveals only one statistical difference (the latter disapproved more of the buyer's refusal to accept the goods, in qD).

One very large New Zealand food products suppliers was "uncertain" in connection with qG, noting that "B [the seller] had to weigh up relative risks and rewards"; and "agreed" with qH, noting that "survival is an imperative for most companies"! 
Some of the "other nationality" respondents came from countries where preliminary results suggest quite different views overall. ${ }^{43}$ One explanation for this finding may be that these respondents "cancel each other out". It remains to systematically compare final results from those countries. Another explanation is that these respondents quickly come to share the norms of their counterparts of New Zealand nationality. Although the rapidity of the assimilation implied by this explanation seems unlikely, there may be some parallels with findings suggesting that foreign companies readily adapt to the legal culture of their host country. ${ }^{44}$ The latter aspect is currently being pursued in further surveys and follow-up interviews of companies in both Japan and New Zealand, which include some subsidiaries of companies incorporated in the other country. Whether or not a rapid assimilation process can be substantiated among foreign students in New Zealand is also an important pedagogical issue.

\section{B Country Bias: Nationalism vs Transnational Intersubjectivity?}

Kato and Young report that there was little country bias among combined law and business students in Japan. ${ }^{45}$ Surveys were administered in Japan involving seven foreign countries as the country of first the buyer, and then the seller. Each contained eight questions (as above). Hence there was a total of fifty-six cases in which statistically significant country bias could have been found, because Japanese responses to each of the eight questions could have differed significantly depending on whether the buyer was from one of the seven foreign countries, rather than Japan. In fact, there was only significant country bias in nine cases. Further, in at least six of those nine cases, Japanese respondents were more favourably disposed towards the foreign country than towards Japan. ${ }^{46}$ Nor did the statistically significant differences congregate in responses to certain foreign countries. The only two countries to receive significantly biased treatment for two questions were France and Korea; all others (China, the US, England, Germany and Australia) received such treatment for only one question. Anyway, that bias was favourable in in both cases

for France and in one of the two cases for Korea. In other words, what little country bias there was suggested that Japanese respondents were anti-nationalistic in orientation.

43 Eg mainland China: Fujimoto and Kato, above n 20.

44 Y Matsumura "Attitudes of Canadian Subsidiaries of Japanese Firms Towards the Law and the Legal System in Canada" (1987) 21 UBC L Rev 209.

45 M Kato and M Young "Nihonjin no Kakkoku Imeji to Keiyakufunso [Contract Disputes and Japanese Images of Various Countries]" (1996) 1096 Juristo 60.

46 Kato and Young (above $n$ 45, 61, 63) interpret as nationalistic a lower overall score for qA in the case of Japanese as opposed to a Korean buyers because they see it as a reluctance to enter into long-term contracts with the latter. However, an alternative interpretation is that this is greater implied criticism of Japanese buyers (text above at $n$ 41). 
In terms of each question, only four ( $\mathrm{qA}, \mathrm{qC}, \mathrm{qD}$ and $\mathrm{qF})$ revealed statistically significant differences in responses from Japanese law and business students combined. Exceptionally, they did exhibit clearly nationalistic orientation with regard to qD: they were significantly more likely to criticise the buyer for threatening to refuse delivery where the buyer was American or British, compared to where the buyer was Japanese. Kato \& Young suggest that this may be a reaction to trade friction, particularly gaiatsu (foreign pressure) from the US. ${ }^{47}$ However, overall, Japanese respondents are not significantly biased against the US with regard to any other question, so this hypothesis remains to be further substantiated.

Indeed, in the other situations where country bias was statistically significant, Japanese respondents were tougher when the buyer was Japanese ( $\mathrm{qH}$ and possibly $\mathrm{qA}$ ) or more lenient on seller which was foreign $(\mathrm{qC})$. Kato \& Young again suggest how some of these responses may be related to contemporary Japanese foreign policy. For instance, they suggest that one reason why Japanese respondents are initially significantly more lenient towards intransigent Korean sellers, and correspondingly less understanding of intransigent Japanese sellers ( $\mathrm{qC}$ ), is a sense in Japan that Japan has the greater obligation to come to the negotiating table when resolving disputes with Korea, as part of making amends for colonising Korea. A similar sense of shame might explain why Japanese respondents are significantly less likely to criticise on ethical grounds Korean buyers who ultimately refused shipment $(\mathrm{qF}) .{ }^{48}$ However, such a direct link between foreign policy or general attitudes in Japan and responses to a contracting scenario seems overly ambitious. It also does not explain well why, when the Korean buyer's threat to refuse delivery is still only a threat (qD), Japanese business students - if not law students - nonetheless object to such behaviour more so than when the buyer is Japanese.

An alternative explanation for systematic differences with regard to particular countries may be that Japanese respondents have strong impressions of ethical norms and legal principles prevailing in those countries, and adjust their responses accordingly. Thus, Japanese law students may be influenced by some general impression that Korean social and legal norms require a seller in this situation to come to the negotiating table (hence the difference in $\mathrm{qC}$ ) and that, more so than in Japan, ethical norms are more amenable to a buyer refusing delivery and precipitating a renegotiation in extreme cases (hence $\mathrm{qF}$ ). That may also explain why business students can turn nationalistic (qD): they probably receive less training than law students, in Japan as in New Zealand, in putting themselves in the other side's shoes in this way. This may also explain why business students are consistently more nationalistic, whereas law students are consistently anti-nationalistic.

\footnotetext{
47 Above n 45, 62.

48 Above n 45, 61, 63.
} 
When the survey results from various countries like Korea have been fully collated, it will be interesting to see the extent to which perceptions of Japanese students are in fact accurate. But such deliberate intersubjectivity in a transnational context, in attempting to respond to this sort of questionnaire, would demonstrate an impressive internationalism. On the other hand, the fact that so few statistical differences have emerged, and the lack of opportunity for follow-up interviews, makes it difficult to substantiate the extent to which this is in fact prevalent in Japanese universities.

New Zealand respondents tended to demonstrate more statistically significant country bias. Further, when they did, it tended to be nationalistic - more critical of a foreign buyer - and directed much more towards Japanese than US buyers. Apparently, this is also the attitude emerging in US responses. ${ }^{49}$ Further, this country bias among New Zealand respondents was more pronounced among law students. That was also true in Japanese responses, but there the attitude of law students was quite strongly anti-nationalistic. It may be that New Zealand law students are less intersubjective in approach. They may be unaware of, or less willing to guess what might be, the relevant socio-legal norms in Japan (which a number might be expected to think favoured renegotiation); even those that did take that step might have been reluctant to adapt their responses to such norms. On the other hand, this preliminary analysis must be treated with similar caution, especially as the sample has been much smaller than for Japan.

\section{LAW AND BUSINESS STUDENTS: LEARNING TO MANIPULATE THE LAW?}

New Zealand responses were also remarkably similar to Japanese responses in that New Zealand business students tended to be tougher on the seller (abstracting from the issue of the latter's nationality), compared to law students. Table 2 shows that business students were significantly more critical of the buyer who had refused to take delivery, on both legal and ethical principle ( $\mathrm{qE}$ and $\mathrm{qF}$ respectively), and disagreed less with the seller's eventual agreement to lower the contract price $(\mathrm{qG})$. Similar significant differences were found when comparing Japanese business and law students. ${ }^{50}$

Above $n$ 45, 62 .

50 Mean values for those questions were, respectively, 2.8 for law students versus 2.55 for business students; 3.13 versus 2.88; and 3.13 versus 3.32 . In Japan, but not in NZ, business students were also significantly more likely to find it "imprudent" to enter into a 5-year fixed term contract, in response to $\mathrm{qA}$ (2.35 versus 2.12). The mean scores in New Zealand responses to this question admittedly went against this pattern (2.17 versus 2.28$)$; but the difference was not statistically significant anyway. The only counter example in Japan was to qD, where law students were more likely to disagree with the buyer's threat not to accept delivery (3.37 versus 3.27). Kato and Young (above $n 21,51$ ) suggest that this may simply be related to non-acceptance being used as a "textbook" example of breach of contract in Japanese contract law courses. 
Table 2: New Zealand Law vs Business Students

\begin{tabular}{|l|l|l|l|l|l|l|l|l|}
\hline & qA & qB & qC & qD & qE $^{*}$ & qF $^{*}$ & qG * $^{*}$ & qH \\
\hline $\begin{array}{l}\text { Law } \\
(158)\end{array}$ & 2.17 & 2.95 & 2.95 & 3.34 & 2.59 & 3.01 & 3.77 & 2.53 \\
\hline $\begin{array}{l}\text { Business } \\
(139)\end{array}$ & 2.29 & 3.06 & 3.15 & 3.44 & 2.34 & 2.53 & 3.43 & 2.42 \\
\hline
\end{tabular}

* Indicates that difference statistically significant at the $95 \%$ Confidence Level

Intriguingly, in Japan, this toughness on the part of business students, or - put differently - the relative leniency of law students, was highly correlated to legal education. Almost invariably, business students who had attended some law courses were significantly less tough towards the buyer. Law students surveyed also tended to become more lenient as they "advanced" through law school. Kato and Young suggest that this pattern may be due to legal education teaching students, especially advanced law students, that the law can be "manipulated". 51 That may be particularly so in Japan, which has a strong realist tradition in private law. ${ }^{52}$

However, even New Zealand law students nowadays probably come away from law school with a degree of cynicism as to the extent to which legal rules are routinely determinant of dispute outcomes, a tendency which may grow as they enter legal practice. ${ }^{53}$ Yet there was no pattern of more advanced New Zealand law students becoming more lenient on the buyer in this situation. On the other hand, law students as a whole do remain more sympathetic to the buyer. At least compared to business students, with much less legal training (if at all), perhaps they do see the law as manipulable to a degree. Such a finding raises difficult questions regarding what law schools and a career in the law should aspire to.

There is an alternative explanation with less challenging implications. Although the questionnaire is formulated in terms of expectations or what should be done, rather than

$51 \quad$ Above $\mathbf{n} 21$.

52 G Rahn Rechtsdenken und Rechtsauffassung in Japan [Legal Thought and Conceptions of Law in Japan] (CH Beck, Munich, 1990) 139-147, 202-264. But also a positivist counter-tendency: L Nottage "Japanese Contract Law, Theory and Practice: 'Plus ça change, plus c'est la même chose?"' in V Taylor (ed) Asian Law through Australian Eyes (LBC, Sydney, forthcoming 1997).

53 See eg J Flood "Doing Business: The Management of Uncertainty in Lawyers' Work" (1991) 25 Law \& Soc Rev 41 in the US, and A Felstiner \& W Sarat, Divorce Lawyers and Their Clients (Oxford University Press, Oxford, 1995) for the US; J Morison and P Leith The Barrister's World and the Nature of Law (Open University Press, Buckingham, 1992) in the UK. 
what the law says must be done, it is conceivable (especially in the context of $\mathrm{qE}$, for instance) that students' understanding of the relevant legal principles may significantly influence their expectations. Thus, it may be that students simply fail to understand or remember the relevant legal principles. Perhaps New Zealand students never got to the end of the standard textbook to learn that frustration of purpose excusing the buyer is extremely rare under New Zealand law (see Part VI below). Japanese students are more likely to come across the doctrine of changed circumstances at an earlier stage of their contract law course, but may remain unaware that it is rarely successfully invoked in Japanese courts (see Part VI below). Perhaps New Zealand students do not appreciate that their law relies on formal reasoning that puts great stress on the parties' initial agreement and leaves little role for direct consideration of extraneous, more substantive factors (see Part VII below).

If so, however, one would expect more advanced students to become tougher on buyers in this situation, especially in New Zealand law schools with their proliferation of elective courses which increasingly draw on and review disparate areas of law. Yet that is belied by the results in both countries. It will be interesting to test students in contract law courses in New Zealand and Japan using a problem modelled on the questionnaire scenario, after spending a similar amount of class time reviewing the relevant legal principles. But one suspects that results would be largely unchanged, due to students in both countries still seeing those legal principles either as casting only a weak "shadow" over the ultimate outcome even in a legal context, ${ }^{54}$ or as largely irrelevant to what should be the outcome in this sort of scenario. Such tendencies would lead back to the need for careful reconsideration of the goals of contemporary legal education and professional ethics.

\section{MEN AND WOMEN: AN ETHIC OF CARE?}

A further thought-provoking similarity between results in Japan and New Zealand is that, quite consistently, men are more likely than women to be tougher on the buyer. Table 3 shows that New Zealand men are significantly more likely to disagree with the proposition that the seller was too inflexible in initially refusing to lower the contract price ( $\mathrm{qC}$ ), and that they are more likely to object to the buyer's subsequent refusal to take delivery, both on legal principle and ethical grounds ( $\mathrm{qE}$ and $\mathrm{qF})$. Similar significant differences were found when comparing Japanese men and women students, although there that pattern extended to responses to all eight questions. ${ }^{55}$

54 R Mnookin and L Kornhauser "Bargaining in the Shadow of the Law: The Case of Divorce" (1979) 88 Yale LJ 1149. 
Table 3: New Zealand Women vs Men

\begin{tabular}{|l|l|l|l|l|l|l|l|l|}
\hline & qA & qB & qC * & qD & qE * & qF $^{*}$ & qG & q H \\
\hline $\begin{array}{l}\text { Women } \\
(167)\end{array}$ & 2.25 & 2.93 & 2.95 & 3.33 & 2.55 & 2.93 & 3.66 & 2.55 \\
\hline $\begin{array}{l}\text { Men } \\
(161)\end{array}$ & 2.26 & 3.08 & 3.20 & 3.50 & 2.32 & 2.60 & 3.58 & 2.41 \\
\hline
\end{tabular}

* Indicates that statistically significant at the $95 \%$ Confidence Level

Particularly in regard to questions like $\mathrm{qC}$ and $\mathrm{qF}$, more clearly asking respondents solely what they think is ethically correct, these differences appear consistent with the "different voice" or "ethic of care" uncovered by Carol Gilligan from her interviews of US women in the 1970s. One test used by Gilligan involved questions regarding the reasons for interviewee responses to a psychological test, "Heinz's dilemma" - should a man steal a drug which he cannot afford to buy, in order to save the life of his wife ${ }^{56}$ Although more dramatic, this "impossible" situation is rather similar to the hypothetical scenario used in the Kato survey. Further, differing responses to questions like $\mathrm{qC}$ and $\mathrm{qF}$ bear some parallels to the way in which Gilligan's two interviewees, Jake and Amy, conceive of the moral problem in very different terms: ${ }^{.7}$

Jake [as] a conflict between life and property that can be resolved by logical deduction, Amy a fracture of human relationship that must be mended by its own thread.

Even at stage (i) of the scenario, New Zealand women begin to favour the buyer, finding the seller's attitude too inflexible (qC). By stage (iii), when the buyer refuses to accept the goods which begin backing up in the harbour, the buyer becomes subject to some mild criticism, but distinctly less than the criticism from New Zealand men (qF). Perhaps this stems from a sense that the seller is still not working hard enough to resolve the buyer's difficulties, but that the buyer also shares the blame by adopting such a tough negotiating stragegy rather than talking matters through. Gilligan's findings mainly came from extensive interviewing. Some of the follow-up interviews of New Zealand companies, in particular, may provide an opportunity to get a better sense of what drives women's responses towards contract renegotiation.

More theoretically, Beverley Brown is cautious about stressing the relational "voice" uncovered by Gilligan, and about attempts to directly incorporate relational considerations

56 C Gilligan In a Different Voice: Psychological Theory and Women's Development (Harvard University Press, Cambridge Mass, 1993 reprint), 25-6. 
into contemporary contract law. ${ }^{58}$ This highlights a further potential difficulty in simply importing social norms and practices into contract law, considered briefly in Part VII below. On the other hand, Mary Joe Frug's post-modern proposal to simultaneously accept and disrupt difference and boundaries highlights the potential instability of New Zealand law's sharp delineation of excuse from strict liability (reviewed in Part VI below). ${ }^{59}$

For those more interested in legal education in this country, the implications from the tentative results of the present survey are also important. Responses to qE show that New Zealand female students are significantly less likely to criticise the buyer by invoking a strict view of contractual liability. New Zealand courts (see Part VI C below), and law teachers who follow the English tradition of defering to the courts, are more likely to follow the stricter view adopted by male students. This creates the potential for female students to be systematically disadvantaged, compared to male students, should they be examined on questions like those posed in this survey.

Law teachers in the US have long raised doubts as to whether some cases and materials used in contract law classes, and they way they are handled, give appropriate messages to women students. ${ }^{60}$ These survey results raise further questions as to how perspectives of New Zealand women might best be given their due in contract law courses. ${ }^{60 a}$

\section{REFORMING THE LAW ON FRUSTRATION OF CONTRACT}

In 1982, John Burrows presented a paper on reforming New Zealand's law of frustration to the Contracts and Commercial Law Reform Committee, one of several parttime law reform committees whose advisory role to the government was superseded by the Law Commission in 1986. The paper was included as an Appendix to the Law Commission's recent Contract Statutes Review. ${ }^{61}$ His overview of arguments for and against reform in this area, and those passages emphasised in some of the quotations below, point to the need for empirical research along the lines suggested in this article. The results from the

58 "Contracting Out/Contracting In: Some Feminist Considerations" in A Bottomley (ed) Feminist Perspectives on the Foundation Subjects of Law (London, Cavendish, 1996) 5.

59 Above n 56, 1046-7.

60 M Frug "Re-Reading Contracts: A Feminist Analysis of a Contracts Casebook" (1985) 34 Am U L Rev 1066.

60a Such issues are being broached by some contract law teachers such as Nan Seuffert at the University of Waikato (personal communication). She is currently exploring extensive resources developed in Australia, publically available ow the Internet (http://online.anu.edu.au/law/pub/teaching_material/citizen/ContractLaw.html).

61 Report No 25 (Wellington, 1993) 275-306. 
Kato/Young survey, as well as the further survey being administered to companies, already dovetail well with some of his specific observations.

Generally, Burrows advocates serious consideration of reform allowing greater relief to a party whose contract has become very onerous due to extreme changes in circumstances. He outlines some of the possible arguments both for and against reform in that direction. His first general point is that the common law tradition is still dominated by the view of contract expressed in Larrinaga \& Co $v$ Societe Franco-Americaine: ${ }^{62}$

No one can tell how long a spell of commercial depression may last; no suspense can be more harassing than the vagaries of foreign exchanges, but contracts are made for the purpose of fixing the incidence of such risks in advance, and their occurrence only makes it the more necessary to uphold a contract and not to make them the ground for discharging it.

Yet, Burrows says, "it should be pointed out that this is not a necessary view. It is not held in other systems - in Japan, for example". 63 In fact, modern Japanese contract law has tended to share the rather strict view of contractual obligation epitomised by the Larrinaga case. This is unsurprising, given its origins in Continental civil codes and legal scholarship in the late 19th and early 20th centuries. However, such an "aleatory" view of contract law, premised on self-responsibility and "formal contract justice", has been subjected to increasing criticism in Japan since at least the $1970 \mathrm{~s} .{ }^{64}$ Allan Farnsworth has noted a similar tradition in some areas of US contract law. ${ }^{65}$ Likewise, Atiyah cites the decision of the House of Lords in Davis Contractors $v$ Fareham UDC, 66 a frustration case where Lord Radcliffe adopted what Dr Barton would view as the "reasonableness" principle, as a milestone in the gradual decline in the ideology of freedom of contract in English law from 1870 to 1980 . Thus, Burrows is in good company in putting in broader perspective the classical English approach to discharge by frustration.

He also quite rightly criticises as misleading the test that subsequently emerged in cases like Davis $v$ Fareham, namely whether performance has become "totally different" from that contracted for. Instead he suggests that another important consideration is whether the risk

(1923) 29 Com Cas 1, 18. Burrows, above n 61, 284.

Above n 61, 284.

K Yamamoto "The Aleatory View of Contract and Critical Contract Theory in Japan" Proceedings of the 1995 Annual Meeting of the Research Committee on Sociology of Law, "Legal Culture: Encounters and Transformations" (Tokyo, 1-4 August 1995), Section Meetings Supplement 2, 143, 143-150. 217, 220. 
of the disruptive event should be borne by one or the other of the parties. Factors listed as relevant to determining the latter also deserve careful consideration: custom in particular types of contract, whether one party is better placed to anticipate and guard against the risks, and whether one party should be taken to have voluntary assumed them. ${ }^{67}$

Burrows' second general point deals with the argument that reformulating the doctrine of frustration to allow greater scope for relief may "induce laxness at the outset in negotiating and pricing contracts, and in their drafting". He notes: ${ }^{68}$

how real this fear is, is difficult to say. If there is merit in such a view, it may simply be an argument for saying that any power to grant relief should be sparingly exercised, rather than that the power should not exist at all.

His third point deals with the argument that any relaxation of the doctrine will lead to a lack of certainty. He notes: ${ }^{69}$

The notion of certainty in contract, insofar as it means anything more than that a contract fixes in advance the risk of changes in circumstances, has been little analysed. Even under present law, contracts are so much at the mercy of circumstance that it is difficult to say that one can predict with certainty the course of their performance or the profit one will make at the end of them. Fancied notions of 'certainty' meant nothing to the builder in Davis $v$ Fareham.

Finally, Burrows summarises the general argument in favour of changing the present law: ${ }^{70}$

the present law can cause great injustice. In many cases sharing the loss caused by the external events would have been more satisfactory thatn allowing it to lie entirely on one party. An even stronger argument is that not all businesspeople would agree with the hard-and-fast rule of the common law. It is not uncommon for parties to enter into major deals in the basis of 'letters of intent' or the vaguest oral understandings, leaving matters to be sorted out reasonably if and when difficulties arise during performance ...

Burrows concludes this general discussion by quoting the extract from Dr Barton's conference paper set out at the start of this article, noting that if the latter is correct the law might well be reformed so as to better accord with the expectations of its subjects. As that quotation and the passages emphasised in this Part show, the area is ripe for empirical research into New Zealanders' expectations. Further, many of Burrows' views as to how

67 Above $\mathrm{n} 61,284$.

68 Above n 61, 286 (emphasis added).

69 Above n 61, 286 (emphasis added).

70 Above n 61, 286 (emphasis added, citation omitted). 
the doctrine could be reformed are supported by the preliminary results of this survey as well as some patterns emerging from ongoing empirical research.

\section{A Duty to Negotiate}

One solution Burrows puts forward for consideration, "although it is difficult to see how it could be enforced, other than by making it a precondition to other forms of relief, is a statutory obligation on parties whose contract has been seriously affected by changes in circumstance to attempt to negotiate a satisfactory modification of their contract". Burrows goes on to suggest that "no doubt this happens now between reasonable parties". ${ }^{71} \mathrm{He}$ concludes: ${ }^{72}$

In Japan this practice has apparently become the norm [two sources omitted]. In that country a contract may be rescinded if a change of circumstance (such as a currency change) has made further performance of the contract unconscionable or contrary to good faith. But notice must be given of rescission and the practice has developed of the promisor proposing a modified contract before exercising the option to rescind. Citizens of common law countries trading with Japanese interests no doubt find this procedure a little unusual but, because of the difficult of enforcing strict performance against someone resident abroad, they normally comply and get around the negotiating table.

\section{Promisor's Duty to Negotiate: Giving Notice and Proposing Variations}

Thus, it seems that the content of a duty to negotiate mooted by Burrows involves at least a requirement that notice be given. It may also involve a further obligation on the promisor (claiming frustration) to propose some variation to the contract in light of the new circumstances. The latter would usually subsume the former. Either, however, would be counter to the traditional English (and New Zealand) view that frustration "brings the contract to an end forthwith, without more and automatically". ${ }^{73}$ Elsewhere, Burrows has criticised this anomalous rule, noting that "it is not a logical necessity that impossibility of performance should operate to discharge a contract. In many Continental systems it is

71 Above n 61, 291. However, here Burrows notes potential difficulties in enforcing such renegotiated agreements because of the "pre-existing duty rule" in Anglo-New Zealand law. Recently, Williams $v$ Roffey Bros \& Nicholls (Constructors) Ltd [1991] 1 QB 1 has begun to eat away at one aspect of that rule. However, it has been criticised by New Zealand commentators ( $B$ Coote, "Consideration and Benefit in Fact and in Law" (1990) 3 JCL 23) and has not been expanded on by New Zealand courts (see L Nottage, above n 2, 200-201 at fn 8). And see now J O'Sullivan "In Defence of Foakes $v$ Beer" (1996) 55 CLJ 219, arguing that the approach adopted by Williams should not be allowed to undermine the rule in Foakes $v$ Beere (1884) 9 App Cas 605.

72 Above n 61, 291-292.

73 Hirji Mulji $v$ Cheong Yue SS Co [1926] AC 497, 505 (per Lord Sumner). See also the decision of the Court of Appeal in Power Co Ltd v Gore District Council (Unreported, 4/11/96, CA 267/95) 29-31. 
viewed rather as a defence ...". ${ }^{74}$ Indeed, this sort of approach is characteristic of both US law and the UN Convention on Contracts for the International Sale of Goods ("CISG"), in force in this country since 1 October 1995, and it leads more naturally to a minimal requirement of notice. ${ }^{75}$ It is also characteristic of Japanese contract law, which has been heavily influenced by the Continental or civil law tradition, as will shortly be shown. It is important, however, to separate out the two aspects Burrows has conflated in the passage reproduced above: legal norms, and the social norms or practices in Japan.

First, as explained by the latter source cited by Burrows, Japanese law provides for two separate doctrines relieving a promisor from performance due to subsequent extreme events: non-attributable impossibility, and the doctrine of changed circumstances (jijo henko no gensoku $).{ }^{76}$ The former is older, stemming from both specific provisions in the Civil Code (promulgated in 1898), and the civil law methodology (mainly German) which was subsequently adopted to make the provisions operate effectively. A starting point is article 415 , which provides that the promisor shall be liable for damages for failing to perform in accordance with the tenor and purport of the obligation, or where performance becomes impossible for any cause attributable to the promisor. By negative implication, the latter has been interpreted to mean that the promisor is not liable where performance becomes impossible for any cause not attributable to the promisor. Non-attributibility clearly covers acts of God. It soon came to include cases of legal impossibility. ${ }^{77}$ By the Second World War, it was being extended to cases of impossibility viewed with "the ordinary good sense of society". ${ }^{78}$ Initially, however, there was a reluctance to extend this doctrine to cases where performance simply became more economically burdensome - what is termed "impracticability" in some common law jurisdictions. ${ }^{79}$ This interpretation was later

74 Above n 14, 642 (citation omitted).

75 E A Farnsworth Contracts (Little Brown, Boston, 1990) 729-30; UCC §2-615(c). B Nicholas "Force Majeure and Frustration" (1979) 27 AJCL 231; Sale of Goods (United Nations Convention) Act 1994, s 2, Schedule, Article 79(1), (3) and (5); Article 79(4). This conceptual structure also leads to better resolution of problems of partial/temporary impossibility, a problem not directly addressed by this research and outside the scope of this article. See, generally, Burrows above $n$ 61, 292-294; G H Treitel Frustration and Force Majeure (Sweet \& Maxwell, London, 1994), ch 4.

76 K Igarashi and L V Rieke "Impossibility and Frustration in Sales Contracts" (1967) 42 Wash L Rev 445.

77 See eg Igarashi $v$ Igarashi 26 Minroku 435 (1920) (seller not liable when goods intended to be produced in its plant could not be delivered on time due to an injunction being granted over the plant).

78 See eg Goto v Shibuya 4655 Horitsu Shimbun 13 (1941) (seller of oil excused because of vessel inavailability during wartime).

79 Cf Ueda v Matsuda 10 D M Roku 1358 (1904) (disallowing rescission). 
relaxed somewhat.$^{80}$ However, although a pattern of relatively liberal relief is discernable, the caselaw is sparse. ${ }^{81}$ This doctrine still does not tend to be applied to cases such as extreme cost escalation in construction contracts, or extreme increases in the market price of the subject matter of the contract (such as land) subsequent to contract formation. ${ }^{82}$ Instead, such cases have been subsumed by the doctrine of changed circumstances.

Before outlining that doctrine, the effects of the Japanese doctrine of non-imputable impossibility should be explored. As mentioned above, Burrows states that first "notice must be given of rescission" by the promisor. Although he is probably refering to the doctrine of changed circumstances, that may well be the situation under the doctrine of nonimputable impossibility as well. ${ }^{83}$ Certainly, it seems that the promisor should give notice to avoid possible liability for breach of collateral contract duties (fuzui gimu). ${ }^{84}$ These duties are underpinned by the principle of good faith and trust (shingi seijutsu no gensoku) set out

T Sawada Subsequent Conduct and Supervening Events (University of Tokyo Press, Tokyo, 1968), 122-123.

Above $n$ 76, 447.

H Kubo "A Comparative Study of the Basic Concept of Impossibility under Japanese, American and Uniform Law" [1991] Sandai Hogaku 567, 576. Further, in a survey of 32 Japanese companies carried out in 1966 , T Sawada (above $n 80,212$ ) noted relatively few disputes where impossibility became an issue: "Destruction of the subject matter or legal prohibition are uncommon. In the strict sense of the word, impossibility is almost unknown in the sale of goods. Legally, parties in certain cases could have claimed impossibility relying on the theory that the performance becomes impossible when the common sense of business so labels it. Yet even under those circumstances many prefer working out adjustments rather than claiming discharge."

83 Article 543 of the Civil Code allows immediate termination, but only by the promisee for impossibility attributable to the promisor. It does not necessarily follow that a blameless promisor can also terminate the contract immediately, ie without notice. Indeed, if the promisor does not perform due to non-attributable impossibility, the promisee is also likely to be delayed in performance. In that case, Article 541 does allow the promisor to terminate the contract, but only upon after a reasonable period.

T Sawada, above, $\mathrm{n}$ 80, 131 (citing a discussion and example given by Hatoyama). Kitagawa (Minpo Koyo (2) - Saiken Soron [Lectures on the Civil Code II: Law of Obligations - General Part] (Yuhikaku, Tokyo, 1993) 16 explains that collateral duties derive from primary duties of performance (kyufu gimu), and thus argues that generally the promisee does not obtain an obligation-right (saiken) to claim performance of collateral duties (ie including specific performance). Breach of collateral duties may give the promisee the right to claim damages. However this does not follow as simply as for breaches of primary duties of performance; there can be considerable remedial flexibility for breaches of collateral duties ( $Z$ Kitagawa Minpo Koyo (3) - Saiken Soron [Lectures on the Civil Code III: Law of Obligations - Particular Part] (Yuhikaku, Tokyo, 1993) 86). 
in article 1 (2) of the Civil Code. ${ }^{85}$ On the other hand, the doctrine of non-imputable impossibility does not specifically provide for the further step mooted by Burrows, namely the promisor proposing some variation of the contract. ${ }^{86}$

The doctrine of changed circumstances was developed somewhat later, largely by Masaaki Katsumoto's classic text published in 1926. Building on the ancient civil law notion of clausula rebus sic stantibus, and German legal theory and case law after the First World War, Katsumoto saw the new doctrine as a concrete expression of the principle of good faith. ${ }^{87}$ It promised relief for a broad range of supervening changed circumstances, including impracticability of performance, provided they were sufficiently substantial. Other orthodox requirements of the doctrine are that the change was not and could not reasonably be foreseen; that it was not attributable to the parties themselves; and that the enforcing or maintaining the original obligations would significantly violate the principles of good faith and fairness (usually, a significant disequilibrium between the respective obligations and no default or objectionable conduct by the party seeking relief). ${ }^{88}$ The economic and social dislocations of the Second World War and its aftermath saw the doctrine come of age.

The remedies or effects provided by the new doctrine also went further than the doctrine of non-imputable impossibility. The primary remedy was to be adjustment of the contractual obligations; termination was to be secondary. Katsumoto proposed that the party seeking relief first demand adjustment from the other, and only terminate the contract if this request for renegotiation was denied. ${ }^{89}$ Obviously, if promisors must and do first seek renegotiation of the contract, before being able to terminate the contract, then Burrows' statement that "notice must be given of recission" is, under this doctrine, imprecise but not incorrect. ${ }^{90}$

The principle of good faith and trust, providing authority for imposing collateral duties, was added to the Code in 1947. However it had been recognised in prior case law and academic theory, drawing on French and especially German law. For a comparative view of its contours, see L Nottage "Form and Substance in US, English, New Zealand and Japanese Law: A Framework for Better Comparisons in the Law of Unfair Contracts" (1996) 26 VUWLR 247.

86 Nevertheless, like other civil law systems, Japanese contract law has no equivalent of the preexisting duty rule, and thus finds it much easier to enforce contractual variations. See Nottage, above $\mathrm{n} 71$.

87 T Sawada, above $n$ 80, 133-4. P Waer "Frustration of Contracts in Japanese Law: The Doctrine of Changed Circumstances" (1987) 20 Law in Japan 187, 189-90. See also R Zimmermann "Heard melodies are sweet, but those unheard are sweeter ..." (1993) 193 AcP 121.

Waer, above n 87, 191-201.

89 Above n 80, 136-137.

90 However, Sawada (above n 80, 138-139) has criticised some Japanese courts for treating the promisor's mere prior refusal to perform as equivalent to a request for renegotiation. 
However, he then states that "the practice has developed of the promisor proposing a modified contract before exercising the option to rescind". Proposing a modified contract is certainly consistent with the doctrine's traditional requirement that renegotiation first be sought; only then does the promisor have a clear "option" to rescind. But, perhaps influenced by a case study mentioned in the second source cited for his abovementioned statement, Burrows now seems to have switched focus, to current practice in Japan. This latter aspect can now be separately considered.

In fact, a 1994 study of the 64 cases then reported where the doctrine of changed circumstances was raised, revealed that in at least 28 cases the promisor had claimed only recission, without first having claimed adjustment. ${ }^{91}$ In some of those 28 cases, the promisor may well have first served notice on the promisee; but this pattern suggests that Japanese practices at least regarding proposals to vary contracts may not be as clearcut as Burrows believed, even when circumstances have changed considerably.

Of course, this data relates only to what was formally claimed in court, rather than what was sought out of court. It is unwise to generalise as to actual practices from reported cases, which are very much "the tip of the iceberg". Moreover, contract adjustment (alone) was sought in 20 cases, and first contract adjustment and otherwise termination in 13 others. Quite regular calls for contract adjustment also emerge from Sawada's surveys and interviews of some 40 Japanese companies as to actual disputes (subsequently litigated only very rarely) which might have been covered by either doctrine. Such calls were made in at least three of the four cases sketched by Sawada, where the doctrine of changed circumstances might have applied. ${ }^{92}$ Further, Sawada found that many contracts included a provision requiring such notice. Such provisions may have reflected pre-existing practices.

Admittedly, Sawada's research dates back to 1966. As mentioned, many believe that Japanese practices have changed and are changing significantly. ${ }^{93}$ Yet survey research currently underway into contemporary practices of Japanese companies - admittedly mainly those with experience in contracting with overseas parties (viz New Zealand companies) - already suggests that while some are careful in planning for contingencies in long-term contracts, they still quite regularly receive requests for and themselves demand adjustment of the contract. In this respect, results so far are not too dissimilar to those of New Zealand companies contracting with Japanese counterparts - or, for that matter, to

91 K Iijima "Jijo henko no Koka to shite no Keiyaku no Tekigo to Kaijo [Rescission and Adjustment of Contracts as Effects of the Doctrine of Changed Circumstances]" (1994) 35 Toritsudai Hogakkai Zasshi 127.

92 Above n 80, 217-22.

93 Above n 34. 
those of US companies generally ${ }^{94}$ Further, although neither this survey of companies nor the present survey of students in both New Zealand and Japan included questions aimed specifically at clarifying practices and expectations as to timely notice-giving, the latter seems likely to be a widespread requirement. It is frequently to be found, especially in international contracts. ${ }^{95}$ Thus, further research into both notice-giving and proposals for renegotiation, by the promisor, seems likely to reinforce the points made more generally by Burrows in this regard.

\section{Promisee's Duty to Renegotiate: In Good Faith}

Further, responses to $\mathrm{qC}$ in the survey of students in both countries help to shed some light on an issue related to those raised by Burrows. This relates to what is or can be expected of the promisee in a renegotiation process triggered by extreme changes of circumstances. Japanese responses to $\mathrm{qC}$ indicate at least mild criticism of the seller's initial refusal to lower the agreed contract price - there was a slight tendency to see that attitude as too inflexible. This was in spite of the hypothetical seller having already demonstrated some flexibility, by acceding to the buyer's request to delay supplies at the agreed contract price. Thus, the attitude expected of the seller (the promisee) would seem to support those who have proposed a duty to renegotiate on the parties, ie including a duty on the promisor.

In Japan, Zentaro Kitagawa first mooted this possibility in 1974, again as a collateral duty underpinned by the duty of good faith. ${ }^{96}$ In 1987, Hiroyuki Kubo took this suggestion a little further, arguing that to prevent an unscrupulous promisee unduly dragging matters out by invoking this duty, it should be imposed on the promisor only after the court had investigated whether the doctrine of changed circumstances could apply, and decided that there was a real possibility that it could. ${ }^{97}$ In 1989, drawing predominantly on German law and legal theory, Yamamoto argued that a duty to renegotiate is implicit in the remedies provided by the doctrine of changed circumstances, and is consistent with a possibly much

94 Weintraub, above $\mathrm{n} 38,18,22$.

95 See eg J Honnold Uniform Law for International Sales under the 1980 United Nations Convention (Kluwer, Deventer/Boston, 2nd ed, 1990) 431; M Furmston "Drafting of Force Majeure Clauses" in E McKendrick (ed) Force Majeure and Frustration of Contract 21 (Lloyds, London, 1991), 24-25.

96 Z Kitagawa "Fukakoryoku Menseki [Excuse through Act of God] II" (1974) 21/2 JCA Journal 8.

97 H Kubo, reprinted in Keizai Hendo to Keiyaku Riron [Contract Theory and Economic Change] (Seibundo, Tokyo, 1992) 244-245. Kubo also suggested that a collateral duty to renegotiate should only be imposed if there had been a "substantial" change of circumstances. However, it is not clear whether this means that the threshold should be higher than the triditional threshold for the doctrine of changed circumstances, which has a similar requirement anyway. 
broader range of duties to renegotiate under contemporary Japanese contract law. ${ }^{98}$ More recently, Takashi Uchida has suggested that the doctrine of changed circumstances aims primarily to encourage good faith negotiations. He has also identified a number of lower court decisions in other contract law areas where a duty to renegotiate was actually imposed. ${ }^{99}$ On the other hand, the case authority is sparse, and it remains to be seen what long-term impact these theories will have on the future path of Japanese contract law. ${ }^{100}$

By contrast, New Zealand remains firmly within the English law tradition. As already mentioned, the conventional view that frustration automatically terminates the contract leaves no room for a duty on the promisor even to notify the promisee, or to propose a variation to the contract, let alone a duty on the promisee to enter into renegotiations in good faith. Nor can New Zealand courts or commentators comfortably turn to a generalised duty of good faith, as a stepping stone for pulling together a broader range of duties to renegotiate, because the traditional view has been that there is no such generalised duty of good faith. ${ }^{101}$ Even if a generalised duty of good faith were to emerge, a further problem will be whether a duty to renegotiate can quickly become accepted under that rubric. ${ }^{102}$ These difficulties are compounded by doubts as to whether even duties to renegotiate agreed on in

98 K Yamamoto "Keiyaku Kosho Kankei no Hoteki Kozo ni tsuite no Ichi Kosatsu [Some Observations on the Legal Structure of Contract Renegotiation Relations]" (1989) 102 Minsho Ho Zasshi 808, 815816. Drawing inspiration from German sources, he relies primarily on $\mathrm{N}$ Horn "Neuverhandlungspflicht [The Duty to Renegotiate]" [1981] AcP 181, 276ff. See also N Horn "Changes in Circumstances and the Revision of Contracts in Some European Laws and in International Law" in N Horn (ed) Adaptation and Renegotiation of Contracts in International Trade and Finance (Kluwer, Boston/Deventer, 1985) 22-23.

99 T Uchida "Gendai Keiyakuho no Aratana Tenkai to Ippan Joko [New Developments in Contemporary Contract Law, and General Clauses] (3)" (1993) 516 NBL 25. Cf Kubo, above n 97,253 . Originally published in 1991, the latter book chapter looks at Japanese contract law doctrines that can be seen as "bordering" on the doctrine of changed circumstances, in an attempt to determine some more general common features and hence future directions. However, a duty to renegotiate is not mentioned.

100 Cf Nottage, above $n$ 51, suggesting that the strong formal streak in Japanese contract law is still powerful and likely to impede their rapid acceptance. But see now K Yamamoto "Saikoshiron ni tsuite - Koshoriron to Keiyaku Riron no Kosaku [Renegotiation: The Interface of Negotiation Theory and Contract Law Theory]" (1996) 63/1 Hosei Kenkyu 1, currently revisiting Horn's theories both in more detail and in broader context.

101 Nottage above n 85, 264-266.

102 The experience in this regard even of Germany and Japan, legal systems with a long tradition of refining a generalised duty of good faith, suggests that the process will be a drawn out and contentious one. Cf also S O'Byrne "Good Faith in Contractual Performance: Recent Developments" (1995) 74 Canadian Bar Rev 70, who identifies an incipient generalised duty of good faith in Canadian contract law, but does not include any suggestion of a duty to renegotiate in her categorisation of the case law. 
a concluded contract are legally enforceable under English or New Zealand law, or whether they are instead too uncertain. ${ }^{103}$

Article 7(1) of CISG provides "that regard is to be had to ... the need to ... promote the observance of good faith in international trade". However, this only applies to "the interpretation of [the] Convention"; good faith is not expressly made a distinct obligation of contracting parties. This peculiar wording represents an unhappy compromise between those supporting the latter approach, and those opposed to including a notion of "good faith" on the ground that it would simply lead to uncertainty. ${ }^{104}$ Commentators are still divided, and national courts are also likely to diverge, in their interpretations of the scope of article 7(1). ${ }^{105}$ However, it seems that no commentator or court has yet been so bold as to propose a duty to renegotiate based on this article. This is not too surprising, given the tentative nature of the duty even in German and Japanese law, with comparatively long experience in defining and refining the contours of a generalised duty of good faith.

A sign of things to come may be the UNIDROIT Principles of International Commercial Contracts. These were developed a decade later than CISG, and with less need for the lastminute compromises which characterise multilateral treaty ngotiation. Parties may adopt the Principles to govern their contractual relationship, and adjudicators may refer to them in deciding disputes. ${ }^{106}$ The latter has already occured in at least one major arbitration in New Zealand. ${ }^{107}$ Article 1.7 imposes an overriding duty of "good faith and fair dealing in

103 Doubts arise because of the hostility of English courts towards "agreements to agree" in a precontractual setting. See eg E McKendrick, "The Regulation of Long Term Contracts in English Law" in J Beatson and D Friedmann (eds) Good Faith and Fault in Contract Law (1995) 305, 321. This is particularly worrying given that a number of $\mathrm{NZ}$ companies already surveyed indicated that they include renegotiation clauses in both domestic contracts and contracts with Japanese parties for a term of over one year. It is questionable, for instance, whether the following clause used by one large food products manufacturer could be enforced:

" $[X]$ and $[Y]$ are to mutually agree on the sales price of the Products. The sales price will be open to review and mutual negotiation during the term of this Agreement should current market conditions and costs of raw materials, manufacturing and transportation substantially change."

104 Honnold, above n 75; Law Commission, Report No 23 (Wellington, 1992) 35-6.

105 See eg F Enderlein and D Maskow International Sales Law. United Nations Convention on Contracts for the International Sale of Goods - Convention on the Limitation Period in the International Sale of Goods: Commentary (Oceana, New York, 1992) 54-56. See generally L Nottage "Trade Law Harmonisation in the Asia-Pacific Region: A Realist's View from New Zealand - and a Way Forward?" [1995] NZLJ 295.

106 See generally M Bonell An International Restatement of Contract Law: The UNIDROIT Principles of International Commercial Contracts (Transnational Juris Publications, Irvington NY, 1994) 120-152.

107 D Williams "The Further Development of International Commercial Arbitration through UNIDROIT Principles of International Commercial Contracts" (1996) 2 NZBLQ 7, 17-21. 
international trade" directly on the parties. Articie 2.15 specifically covers bad faith at the contract formation stage, whereas article 5.3 requires each party "to co-operate with the other party when such co-operation may be reasonably be expected for the performance of that party's obligations". These provisions seem more likely than CISG to lead to a duty to renegotiate on the promisee, should the promisor invoke force majeure under article 7.1.7, even though such a duty is not expressly set out therein. Such a duty seems all the more likely when the promisor invokes "hardship" as defined in article 6.2, which explicitly entitles the "disadvantaged party ... to request renegotiations". 108

Thus, this brief discursus into Japanese law and developments in international trade law suggests that New Zealand lawmakers may need to begin considering a perhaps more radical notion than that proposed by Burrows: a duty to negotiate imposed on the promisee, in extreme changes in circumstances. ${ }^{109}$

\section{B Court Variation and Release}

A second possible avenue for reform put forward by Burrows for consideration can now be more shortly dealt with. Rather than automatic total discharge following a finding of frustration, the traditional English and New Zealand law approach, the courts might have: ${ }^{110}$

power to grant just relief in the form of variation or cancellation of particular terms; performance with compensation by one party; or total discharge on conditions. This would move the court's discretion in the direction suggested by Denning LJ in his well-known judgment in British Movietonews Ltd $v$ London \& District Cinemas Ltd [1951] 1 KB 190; [1952] AC 166 (which was later disapproved in the House of Lords).

Burrows then considers arguments against such remedial flexibility. Foremost is the concern that any attempt to reform the law in this way would lead to total destruction of certainty in contractual relationships. Secondly, it could detrimentally affect insurance. A seemingly related argument is that this will require judges to become economists: able to calculate the effect of their decisions not only on the parties, but also the long term effects on

108 The wording is in terms of a request, rather than a right to insist on renegotiations; but that seems unlikely to slow a court whose domestic legal system recognises some mandatory degree of mandatory renegotiation. See generally D Maskow "Hardship and Force Majeure" (1992) 40 1992 AJCL 657, who however does not refer to this issue either.

109 Cf also the discussion on relevant US law as applied to certain international disputes in S Burton "Combining Conciliation with Arbitration in International Commercial Disputes" (1995) 18 Hast Int \& Comp L Rev 637, especially 647-650.

110 Above n 61, 288-89. 
contracts of that type and on commercial practices. ${ }^{111}$ Against this, it should be noted that since Burrows' paper was initially prepared over a decade ago, one of New Zealand's most senior judges has consistently called on the legal profession to meet this challenge, and some are now seem to be meeting this challenge. ${ }^{112}$ Similarly, a final argument envisaged by Burrows a decade ago, that many statutory reforms in New Zealand providing fairly wideranging discretions to the courts first need "a chance to bed down and be thoroughly tested" can now be met by Law Commission's recent review of those statutes, which showed that on the whole they have not created great problems. ${ }^{113}$

Indeed, as Burrows argued, it is not a major step to allow judicial interference on grounds such as harshness, after conclusion of the contract, when it is already allowed at the time of contracting (as under the Minors' Contracts Act 1969). Burrows also points to the close parallels between the law of frustration and that relating to common mistake, where the Contractual Mistakes Act 1977 already provides for discretionary relief. ${ }^{114}$ Another argument is that total automatic discharge is a very blunt instrument, softened still only quite unsatisfactorily by the Law Reform (Frustrated Contracts) Act 1944, and that a discretionary power would permit less extreme solutions better attuned to what is required in particular contractual relationships. ${ }^{115}$ Finally, and importantly for present purposes, Burrows again turns to contract practice, arguing that: ${ }^{116}$

Some [standard form New Zealand] building contracts ... allow a very wide power to the supervising engineer to vary the contract during the course of performance. What is here being suggested would lead to no more uncertainty than this.

Of course, this assumes that judges will be able to apply standards to resolve such problems as consistently as experts in the trade. This leads back to the question raised earlier as to the proper role of, and the training for, the modern judiciary. Interestingly, Schmitthoff also considers contract practices, as to "hardship" and "third-party intevener"

111 Above n 61, 289-90.

112 The calls have been made especially by the current President of the Court of Appeal, Sir Ivor Richardson (see J Smillie "Formalism, Fairness and Efficiency: Civil Adjudication in New Zealand" [1996] NZ L Rev 254). An example of them being met, at least in part, is the formation of the NZ Law and Economics Association (http://www.liinz.org.nz/liinz/other/leanz/).

113 Above n 61, 290.

114 Above $n$ 61, 290. This is regularly pointed out in US law: Farnsworth, above n 75, 727-9; Kull "Mistake, Frustration and the Windfall Principle of Contract Damages" (1991) 43 Hastings LJ 1.

115 Above n 61, 290, 295-306 (on difficulties with the Act: see also J Carter and G Holhurst "Gigs N' Restitution - Frustration and the Statutory Adjustment of Payments and Expenses" (1996) 10 JCL 264. 
clauses and their operation especially in long-term international contracts, in proposing reform of English law to allow for adjustment by the courts. ${ }^{117}$ This also implies considerable confidence in the judiciary to develop consistent standards, just as other third parties (eg experts and arbitrators in specific industries) and sometimes the parties themselves (eg through trade associations).

Again, Burrows refers to Continental jurisdictions, to bolster the possible case for a court power to adjust the contract. He refers to both German and French law, noting however that in the former case the power is not exercised lightly, and that in the latter it is limited to public contracts of a non-speculative type. ${ }^{118} \mathrm{~A}$ similar reluctance is evident in Japanese law. Of the 64 reported cases which deal with the doctrine of changed circumstances (mentioned at Part VI B above) adjustment alone was claimed in only 20 cases and recognised in only 9 of them; adjustment or otherwise termination was claimed in 13 other cases, but adjustment was approved in only 4 of them. ${ }^{119}$

On the other hand, as even the US experience shows, the possibility of court adjustment of the contract seems to welcomed by businesspeople in some situations. In Russell Weintraub's recent survey, ${ }^{119 a}$ US companies were asked what should be done in the following situation:

Company A has contracted to sell B a fixed quantity of fuel oil per month at a fixed price for 10 years. An unprecedented OPEC oil embargo causes the cost of the oil to A to far exceed the price that $B$ has agreed to pay. A's loss over the 10 years of the contract would be so large as to require liquidation of $A$. B can pass on the added cost of oil to its customers without suffering a competitive disadvantage. A refuses to deliver the oil at the contract price, and B sues $\mathrm{A}$ for the difference between the contract price of the oil and the much higher price that B must pay to obtain oil from other sources.

One might expect respondents to be more lenient than for the Kato/Young survey hypothetical. There is no indication that supplier A initially obtained an exceptionally good deal, which might lead respondents to hold A to its bargain. This is also a situation

117 C Schmitthoff "Hardship and Intervener Clauses" [1980] JBL 82.

118 Above n 61, 289. See generally Horn, above n 98; and P Legrand "The Case for Judicial Revision of Contracts in French Law" (1989) 34 McGill L Rev 909.

119 Above n 91. Termination was allowed in four others.

119a Above n 38. 
where the supplier is seeking to be excused, rather than the buyer, who runs some risk of being treated less leniently. ${ }^{120}$ The results are nonetheless quite surprising.

Only 35\% thought that $B$ should receive a judgment for the difference between the contract price and the market price. Almost $14 \%$ thought A should be excused and, perhaps most intriguingly, $46 \%$ thought that "the contract price should be adjusted to avoid ruinous loss to A, but to give B a significant savings over current market price". ${ }^{121}$ Weintraub notes that the much publicised $A L C O A$ case remains a rare example of a US court adjusting a contract in similar circumstances, but also that the judgment and the general possibility of court adjustment may better encourage a renegotiation and settlement process. ${ }^{122}$ Survey responses from US companies may indicate support for this view.

Responses so far to the same question put to Japanese companies indicate a rather similar pattern. Only around $20 \%$ would award B expectation interest damages, but only $8 \%$ would simply excuse $\mathrm{A}$; around $64 \%$ favoured court adjustment. ${ }^{123}$ Although, as mentioned, the latter remedy is rarely invoked by Japanese courts, the fact that it is more readily available under Japanese law suggests that the law is more consistent with what Japanese businesses expect of it, compared to the situation in the US.

The same cannot be said of New Zealand, where the gap between legal rules and businesspeople's expectations seems even greater than in the US. Responses so far to the same question put to New Zealand companies again reveal a rather similar pattern. They are perhaps less lenient: around 39\% would award B expectation interest damages whereas less than $9 \%$ would excuse A. However, around $52 \%$ favour court adjustment in the circumstances, even though this remedy remains unavailable under the traditional law of

120 For instance, Posner J in Northern Indiana Public Service Co v Carbon County Coal Co 799 F 2d 265 (1986) treated the buyer's claim as one of frustration of purpose, and went on to disallow it. Treitel (above $n$ 74, 283-4) convincingly argues that this is misconceived because the buyer simply seemed to be claiming that the goods had become too expensive (effectively a claim of commercial impracticability), not that they had become useless. On the whole, though, buyers (or recipients of goods or services) appear to have more scope for arguing frustration of purpose compared to suppliers, while such claims tend to be treated more strictly by the courts (Treitel, above $n 74,60$ ).

121 Weintraub, above $n 38,41$. (The discrepancy of $5 \%$ is from those who responded "other".)

122 Aluminium Company of America $v$ Essex Group Inc 499 F Supp 53 (1980). Weintraub, above n 38 , 42-43. See also R Buxbaum "Modification and Adaptation of Contracts: American Legal Developments" in N Horn (ed) above n 98, 45. Kubo (above n 97, 162-163) also observes that the $A L C O A$ case has not led to more contract adjustment by other US courts; but this seems to miss the point about the different shadow cast on renegotiation processes simply by having this remedy potentially available. See also Macaulay et al, above n 10, 731-734.

123 The discrepancy of $8 \%$ is from those who responded "Other". 
frustration. Of course, if New Zealand companies also favour this remedy as a means of encouraging renegotiation, other means are conceivable. One is for courts to bend the rules applicable to damages or other remedies ostensibly granted to B (the promisee), as occurred in the Westinghouse litigation. ${ }^{124}$ However, no New Zealand companies have proposed this alternative in response to the abovementioned scenario. If New Zealand lawmakers do wish to defer to the expectations revealed by this survey question (a point raised in Part VII), then these preliminary results reinforce the recommendation of Burrows and others that contract adjustment should be available as a remedy for frustration, even if a residual remedy to be exercised only sparingly. ${ }^{125}$

Again, although this possibility is not spelled out in article 79 of CISG, it is to be found in article 6.2 of the UNIDROIT Principles, which provide that if the parties cannot reach agreement within a reasonable time:

If the court finds hardship it may, if reasonable,

(a) terminate the contract at a date and on terms to be fixed; or

(b) adapt the contract with a view to restoring its equilibrium.

Burrows concludes that if a judicial discretion is to be granted, formulating the conditions in which the discretion can be exercised is of crucial importance. ${ }^{126}$ The suggested formulation differs somewhat from that contained in both CISG and the UNIDROIT Principles. This point leads into a third possible avenue for reform proposed by Burrows for consideration, namely changing the threshold requirements for frustration of contract. This issue also benefits from some insights from preliminary results from the present empirical study.

\section{Lowering the Threshold}

Burrows suggests that a statutory criterion for frustration could be formulated in New Zealand which would be easier to meet than that presently adopted. ${ }^{127} \mathrm{He}$ notes that the English law tradition continues to set a high threshold for relief under the doctrine.

124 Buxbaum, above $\mathrm{n}$ 122, 51-52.

125 Another interpretation of these results, now being explored in follow-up interviews, is that respondents are calling for adjustment under insolvency law, rather than contract law. (On possible overlaps between the two, see generally R Hillman "Contract Excuse and Bankruptcy Discharge" (1990) 44 Stan L Rev 90. However, the point seems a fine one, and it has not yet emerged in written comments to this question.

126 Above n 61, 291.

127 Above $\mathrm{n} 61,287$. Of course, the courts could also relax the preconditions, and it may prove easier to do so in New Zealand than to adopt the other possible reforms discussed above. 
Elsewhere, Burrows has suggested that despite the potential for some relaxation opened up by the High Court of Australia in 1985, for instance, this high threshold remains a feature of both English and New Zealand law. ${ }^{128}$ This trend has continued into more recent times. ${ }^{129}$ Burrows suggests that part of the reason for this is the drastic solution, automatic total discharge, which remains the only remedy. ${ }^{130}$

Burrows suggests that another reason is that English law quickly developed a strong insistence on the absolute nature of contractual liability, and contrasts Continental systems which have traditionally started with the notion of fault-based liability. ${ }^{131}$ Some doubts have recently emerged as to precisely when this approach emerged in England, ${ }^{132}$ whereas others have pointed out the increasingly strict nature of contractual obligation in civil law jurisdications generally and in Japan in particular. ${ }^{133}$ Yet the point remains that civil law jurisdictions do seem to set a somewhat lower threshhold in excusing performance.

Equally important is Burrows' point about US law. UCC §2-615 was enacted to provide more scope for excuse, by deliberately moving away from traditional (and quite precisely delineated) common law categories of "impossibility" towards a more general standard of "impracticability". The latter was seen as less demanding. ${ }^{134}$ It should be added that a more liberal standard was also perceived particularly by Karl Llewellyn, the primary impetus behind the Code, as compatible with US business practices and expectations at the time. ${ }^{135}$ Yet, as Burrows points out and more recent commentators generally agree, ${ }^{136}$ changing the terminology has made little difference to court outcomes: US courts remained quite reluctant to grant excuse. The same can be said of the development of

128 J Burrows, Update on Contract 1991 (NZLS Seminar, Wellington, 1991), 15: "even four swallows [New Zealand cases where frustration was allowed] do not make a summer".

129 See eg The Super Servant Two [1991] 1 Lloyd's Rep 1 (albeit more on issue of self-inducement of contract); Power Co, above n 73.

130 Above n 61, 277.

131 Above n 61, 277.

132 J Wladis "Common Law and Uncommon Events: The Development of the Doctrine of Impossibility of Performance in English Contract Law" (1987) 75 Geo L J 1575.

133 See, respectively, $\mathrm{G}$ Treitel Remedies for Breach of Contract: A Comparative Account (Clarendon Press, Oxford, 1988) ch1; and H Kubo above n 82, 575-578.

134 Above n 61, 287.

135 Above n 61, 287-8287; J Wladis "Impracticability as Risk Allocation: The Effect of Changed Circumstances upon Contract Obligations for the Sale of Goods" (1988) 22 Ga LR 503, 568-569.

136 Above n 135, 584 (although three counter-examples continue to surface: 588-589). 
the doctrine of changed circumstance in Japan. ${ }^{137}$ Only 24 of the 64 cases reported (as of 1994) clearly granted relief. ${ }^{138}$

Certainly, it is too much to expect that some particular wording can be devised that will always adequately mark out the line between excuse and enforcement of performance even if one could agree where that line should be drawn. ${ }^{139}$ This has proven so with CISG, where there are grave concerns as to whether different national courts will apply article 79 consistently, even though many of its concepts can be seen as reflecting a "common core" of concepts found in many domestic legal systems. ${ }^{140}$ Interestingly, the UNIDROIT Principles follow the wording of article 79 only in article 7, adding a further article 6 on "hardship" (partially cited above) introducing concepts which are different again. As in other areas of contract law, such as remoteness of damage, substantive considerations may be more important in devising and implementing an appropriate test than agonising over the phraseology used. ${ }^{141}$ The former approach can lead more naturally into more systematic analysis of current contracting practices and expectations. If New Zealand lawmakers find that approach appealing, preliminary responses of firms to the scenario set out in Part VI B above also suggest that serious thought should be given to setting the threshold for relief so that it is more readily passed in that or similar scenarios. However, as Burrows noted in his earlier study, a lower threshhold may work more satisfactorily where the consequences were less drastic, such as court power to vary the contract. ${ }^{142}$ Responses from New

137 Thus, the following comments (emphasis added) are quite incorrect if they imply that Japanese courts more readily grant relief:

"Instead of trying to spell out all possible contingencies and provisions for enforcement in inflexible terms, the Japanese prefer to handle problems as they arise, often recognizing the doctrine of changed circumstances" (March, above n 2, 112).

"There was the added risk that the Japanese courts might refuse to enforce the Australian judgment based on radically different law [favouring strict contractual liability] from that which the Japanese courts recognize as applicable in the circumstances" (P Opas "What Happens when the Contract becomes Unprofitable?" (1973) 1 ABLR 59, 62).

138 Above, $\mathrm{n} 91$.

139 Ultimately, perhaps, "the wisdom of Solomon": A Corbin Corbin on Contracts (West, St Paul Minn, 1962) 371-372. Cf P Wangerin, "The 'Wisdom of Solomon': Reliance, Unconscionability and Excuse in the Law of Contracts" (1992) 5 JCL 241.

140 H Smit "Frustration of Contact: A Comparative Attempt at Consolidation" (1958) 58 Col L Rev 287, J B Marcantorio "Unifying the Law of Impossibility" (1984) 8 Hast Int \& Comp L Rev 43.

141 Cf Cooke P in McElroy $v$ Milne [1993] 1 NZLR 39 with R Ahdar "Remoteness, "Ritual Incantation" and the Future of Hadley $v$ Baxendale: Reflections from New Zealand" (1994) 7 JCL 53.

142 Above n 61, 288. 
Zealand firms (as well as US and particularly Japanese firms) indeed suggest that most prefer relief by court adjustment, rather than outright excuse.

A specific aspect of the threshold test for frustration which deserves urgent reconsideration is that of foreseeability. English caselaw has often required that the supervening event not be foreseen or foreseeable. This also appeared to be a major reason for the High Court's rather abrupt rejection of a claim of frustration in a recent case. ${ }^{143}$ Foreseeability of earthquakes in New Zealand was also a factor in disallowing frustration in Hawkes Bay Electric Power Board $v$ Thomas Borthwick \& Sons (Australia) Ltd. ${ }^{144}$ Yet foreseeability per se has recently been criticised in England, New Zealand, the US and Japan. ${ }^{145} \mathrm{~A}$ frequent criticism is that even if some events are actually foreseen, the parties may have decided that the background legal principles would allow relief if they eventuated anyway, and hence have not provided for such events in their contract document. Disallowing relief on the ground that the event was reasonably foreseeable is also seen to demand too much of the average contracting party and to lead courts, afforded the luxury of hindsight, to increasingly circumscribe relief as evidence accumulates as to what extreme changes have previously arisen to significantly derail contract performance.

Such doubts are supported to some extent by some responses already from Japanese companies to a scenario similar to that set out in Part VI B above, but where the extreme cost increase to the supplier is caused by a natural disaster like the Kobe earthquake of 17 February 1995, rather than purely economic disclocation caused by an oil embargo. One respondent changed its preference from outright excuse to insistence that the supplier perform the contract as originally agreed, if the natural disaster was "foreseeable". As the survey was administered less than 18 months after this disastrous earthquake, this response from a firm in the area affected may represent a tougher line; but it begs the question of whether earthquakes are foreseeable or not. Further, three other respondents (including two from the area affected) changed the prefered response from court adjustment to outright excuse, despite the fact that the Kobe earthquake must have still weighed heavily

143 Gore District Council v Power Co Ltd [1996] 1 NZLR 58, 69. Cf the Court of Appeal's much more extensive treatment (above n 73, 26-33).

144 [1933] NZLR 873. Cf Burrows, above n 14, 637 (noting other factors which may have been more decisive in that decision). The aftermath of the great Napier earthquake raise tantalising questions for further empirical research. For instance, virtually all survey plans and land title certificates held by government departments and solicitors or banks were destroyed: $R$ McGregor The Great Quake (Regional Publications Ltd, Napier, 1989) 53.

$145 \mathrm{~J}$ McInnis "Frustration and Force Majeure in Building Contracts" in E McKendrick (ed) Force Majeure and Frustration of Contract (Lloyds, London, 1991) 151, 152-153 (but cf A Phang "Frustration in English Law - A Reappraisal" [1992] Anglo-Am LR 278, 289-294); Burrows, above n 14, 637; Farnsworth, above n 75, 716-8; Kubo, above n 97. 
on their minds. Although these reactions are not so clear in preliminary responses from New Zealand businesses, they do call into question a strict requirement of non-foreseeability in this area of law.

\section{FORM, SUBSTANCE, AND NEO-PROCEDURALISM}

An interest in actual practices and expectations of contracting parties underlies the approach towards New Zealand's contract law adopted by both Burrows and Barton. More recently, McLauchlan has also argued that the courts do strive to recognise those expectations, provided they are "reasonable". ${ }^{146}$ Overall, the argument often appears to be that if there is a "gap" between contract practice and contract law, both the courts and the legislature should try to narrow it. This Part concludes by sketching some implications of that approach.

The "form-substance" distinction developed by Patrick Atiyah and Robert Summers can be usefully extended to compare contract law and legal institutions in New Zealand and Japan, as well as England and the US. ${ }^{147}$ Courts and legislative bodies in legal systems more open to substantive reasoning - involving "moral, economic, political, institutional or social considerations"148 — will be more likely to attempt to stay in tune with the actual practices and expectations of contracting parties. Their counterparts in more formal systems may still attempt to reduce gaps, but rather by encouraging or indeed forcing practices and expectations to conform to the dictates of the law. The US and Japan appear to more consistently adopt the former stance. ${ }^{149}$ From time to time, English and New Zealand judges also insist that they aim to decide cases in accordance with community practices and expectations. ${ }^{150}$ However the overall impression is of a more formal approach to contract law adjudication. ${ }^{151}$

146 D McLauchlan "The 'New' Law of Contract in New Zealand" [1992] NZ Recent L Rev 436.

147 Nottage, above $\mathrm{n} 85$.

148 P S Atiyah and R S Summers Form and Substance in Anglo-American Law: A Comparative Study of Legal Reasoning, Legal Theory, and Legal Institutions (Clarendon Press, Oxford, 1987) 15.

149 See eg Llewellyn's efforts in the middle of this century to codify sales law in the UCC (above $n$ 135), and Trakman (above n 30) 33-37. It also drives the current review of Article 2 (Preliminary Report, 1991 (above n 12). Uchida's analysis (above n 13, 99) suggests that this tendency also characterises contemporary Japanese contract case law. See also V L Taylor "Continuing Transactions and Persistent Myths: Contracts in Contemporary Japan" (1993) 19 Melbourne University Law Review 352. But cf Nottage, above n 52.

150 Eg P Devlin "The Relation between Commercial Law and Commercial Practice" (1951) 14 MLR $249,266$.

151 J Bell Policy Arguments in Judicial Decisions (Clarendon Press, Oxford, 1983) 244-245 concludes that the "interstitial legislator" model better characterises the approach of English judges. Cases 
The pervasiveness of these tendencies remains to be more fully explored. ${ }^{152}$ However, if Atiyah and Summers' message of deep-rooted systematic differences between legal systems can be extended to New Zealand in this way, then it also raises difficult questions of general legal theory. The increasing complexity of contemporary society raises grave doubts as to the ability of formal reasoning to order social relations, and even as to its foundation in traditional liberal philosophy. Recent empirical studies into actual practices and expectations in certain contracting situations raise difficult substantive arguments as to whether those should be simply absorbed into the law or kept separate to promote values such as efficiency or party autonomy. ${ }^{153}$ Some argue that substantive reasoning driven by an instrumentalist philosophy is no longer feasible or normatively tenable. The way forward seems to be "neo-procedural" visions of law, which focus on processes involved in interactions between increasingly differentiated social sub-systems, including the legal system; between people in webs of relations coming to terms with the normative force of positive law; or between people constrained by patterns of argumentation. ${ }^{154}$ The possibility of shedding some new light on these debates in a New Zealand context further underpins the ongoing empirical research introduced in this article.

such as McCutcheon v McBrayne [1964] 2 All ER 430, 438-439 (per Lord Devlin) then show how narrow the interstice for judicial creativity can be. On conflicting directions in New Zealand appellate courts, see generally J Smillie, above n 112. For recent critiques of predominantly formal reasoning in New Zealand contract cases, see D McLauchlan "The Plain Meaning Rule of Contract Interpretation" (1996) 2 NZBLQ 80, and "Subsequent Conduct as an Aid to Interpretation" (1996) 2 NZBLQ 237.

152 Practitioners' views on the present state of contract law, and its prefered state (likely to bear some relation to contract practices), could also be systematically ascertained. Cf J Gava and P Kincaid "Contract and Conventionalism: Professional Attitudes to Changes in Contract Law in Australia" (1996) 10 JCL 141.

153 See eg the summary of some of the divergent views at a symposium on "Law, Economics and Norms": R Pildes "The Destruction of Social Capital Through Law" (1996) 144 U Pa L Rev 2055, 2055-2056.

154 See, respectively, G Teubner "Substantive and Reflexive Elements in Modern Law" (1983) 17 Law and Society Review 240; T Tanase "Ho no Imiryokai to Community [Community and Understanding Meaning in Law]" in T Tanase (ed) Gendai no Fuhokoiho [Modern Tort Law] 291 (Yuhikaku, Tokyo, 1994); K Yamamoto "Keiyaku to Kosho [Contract and Negotiation]" in S.Tanaka (ed) Gendai Riron Hogaku Nyumon [Introduction to Modern Legal Theory] 48 (Horitsu Bunkasha, Tokyo, 1993). 
The Victoria University of Wellington Law Review and the New Zealand Association for Comparative Law gratefully acknowledge financial support for this publication from:

\section{SHOWA LAW OFFICE}

Nishitenma 4-4-18, Umegae-chuo Bldg, Suite 700, Kita-ku, Osaka, Japan 530

Telephone

(+81) (6) 364-3224

Facsimile 364-3226

Telex 523-3020 SHOLAW J

Partners:

Mr Yoshio Iimura

Mr Takeo Mizuno

Mr Mutsuo Tahara

Mr Yoshio Kurihara

Mr Toru Masuichi

Mr Keijiro Kimura

Mr Hiroji Indo

Mr Hisayuki Miyashita

Mr Takashi Hattori
Associates:

Mr Masafumi Kawamura

Mr Norihiko Akashi

Ms Ayako Kawano

Mr Nobuhiro Kagoike

Office Manager:

Mr Hideo Yoneyama 